\title{
Correction to: Bilateral spontaneous thrombosis of the pampiniform plexus mimicking incarcerated inguinal hernia: case report of a rare condition and literature review
}

Sabyasachi Bakshi, ${ }^{1,2}$

\section{Correction to: Surg Case Rep https://doi.org/10.1186/s40792-020-00810-3}

In the original publication of this article [1], there is a correction in Table 2. The revised Table 2 is shown below.

Table 2 Comparative characteristics of present study

\begin{tabular}{|c|c|c|}
\hline Parameters & $\begin{array}{l}\text { Findings after literature } \\
\text { review }\end{array}$ & Findings of present case \\
\hline Age at presentation & $\begin{array}{l}\text { Mean age was found } \\
32.27 \text { years.(range } \\
7-65 \text { years) }\end{array}$ & $\begin{array}{l}\text { Present case is the eldest } \\
\text { of all reported subjects till } \\
\text { date. }\end{array}$ \\
\hline Location (side) & $\begin{array}{l}\text { Left sided in } 70 \% \\
\text { cases, } 25 \% \text { in right } \\
\text { side. }\end{array}$ & $\begin{array}{l}\text { Bilateral thrombosis were } \\
\text { found at presentation. }\end{array}$ \\
\hline Duration of pain & $\begin{array}{l}\text { Varied duration. } \\
\text { Ranges from hours } \\
\text { to } 5 \text { weeks }\end{array}$ & $\begin{array}{l}\text { In present case mild } \\
\text { dragging pain started } \\
6 \text { weeks ago. }\end{array}$ \\
\hline Predisposing factors & $\begin{array}{l}\text { Majority reported } \\
\text { heavy physical works. }\end{array}$ & $\begin{array}{l}\text { Subject in present case } \\
\text { was also a active physical } \\
\text { labor }\end{array}$ \\
\hline Initial diagnosis & $\begin{array}{l}\text { Majority was diagnosed } \\
\text { preoperatively as } \\
\text { incarcerated inguinal } \\
\text { hernia. }\end{array}$ & $\begin{array}{l}\text { Present case was also } \\
\text { diagnosed as incarcerated } \\
\text { inguinal hernia in } \\
\text { emergency department. }\end{array}$ \\
\hline $\begin{array}{l}\text { Primary Investigation } \\
\text { and management }\end{array}$ & $\begin{array}{l}\text { USG Doppler flow study } \\
\text { confirmed majority of } \\
\text { the cases and majority } \\
\text { were managed by } \\
\text { surgical excision. }\end{array}$ & $\begin{array}{l}\text { USG Doppler confirmed } \\
\text { diagnosis. But the case } \\
\text { was managed } \\
\text { conservatively. }\end{array}$ \\
\hline
\end{tabular}

The original article can be found online at https://doi.org/10.1186/s40792020-00810-3

Correspondence: dr.bakshi.s@gmail.com

${ }^{1}$ Department of General Surgery, BSMCH, Bankura, India

${ }^{2}$ Hooghly, West Bengal 712103, India

照 Springer Open
Published online: 23 March 2020

\section{Reference}

1. Bakshi. Bilateral spontaneous thrombosis of the pampiniform plexus mimicking incarcerated inguinal hernia: case report of a rare condition and literature review. Surg Case Rep. 2020;6:47.

(c) The Author(s). 2020 Open Access This article is licensed under a Creative Commons Attribution 4.0 International License, which permits use, sharing, adaptation, distribution and reproduction in any medium or format, as long as you give appropriate credit to the original author(s) and the source, provide a link to the Creative Commons licence, and indicate if changes were made. The images or other third party material in this article are included in the article's Creative Commons licence, unless indicated otherwise in a credit line to the material. If material is not included in the article's Creative Commons licence and your intended use is not permitted by statutory regulation or exceeds the permitted use, you will need to obtain permission directly from the copyright holder. To view a copy of this licence, visit http://creativecommons.org/licenses/by/4.0/. 